\title{
CONCEPTUAL FOUNDATIONS OF PROFESSIONAL TRAINING OF FUTURE PRACTICAL PSYCHOLOGISTS
}

\section{В. М. Синишина \\ Державний вищий навчальний заклад «Ужгородський національний університет» КОНЦЕПТУАЛЬНІ ЗАСАДИ ПРОФЕСІЙНОЇ ПІДГОТОВКИ МАЙБУТНІХ ПРАКТИЧНИХ ПСИХОЛОГІВ}

\begin{abstract}
The scientific achievements of leading scientists on the selected theme are analyzed and leading ideas, concepts, and main definitions of the research are identified in the article.

The creation of proper psycho-didactic conditions in institutions of higher education, which serve as a basis for the formation of professionally significant competences, the development of personal creative potential and active public position in future practical psychologists, is updated. It is argumented that the educational system built on the conceptual foundations of professional training makes it possible to effectively content the educational disciplines, and therefore effective fundamental knowledge, professional-oriented skills, advanced skills, professional norms and values, which have the highest degree of generalization of social phenomena and processes.

It is proved that the concept of the study of practical psychology combines professional methodological, philosophical and general scientific principles and scientific-methodological approaches, which are directed at the revealing future professional activity. The outlined conceptual foundations of professional training allow us to modify the educational process in higher education according to the individual needs of future practical psychologists.

The methodological analysis of educational phenomenon of practical psychology in institutions of higher education on four basic levels is offered: philosophical-theoretical (evolutionary-theoretical formation of the specialist and his or her effective functioning), methodological (formation of the system of world-view and semantic individual formations for realization of individual's educational skills and abilities), specific-scientific (acquisition of fundamental knowledge about professional activities) and technological (effective use of methods and techniques of research for acquisition of true empirical knowledge).

The conclusion about the importance of outlining of conceptual foundations in the system of professional training of future practical psychologists is made.
\end{abstract}

Key words: professional training; institutions of higher education; conceptual foundations of professional training; students; future practical psychologists.

Анотація. У статті здійснено аналіз наукових доробок провідних науковців з обраної теми та виокремлено провідні ідеї, концепції, ключові дефініції дослідження.

Актуалізовано створення належних психодидактичних умов у закладах вищої освіти, які слугують основою для формування професійно-значущих компетентнісних якостей, розвитку особистісного творчого потенціалу та активної громадської позиції в майбутніх практичних психологів. Аргументовано, що вибудувана на концептуальних засадах професійної підготовки освітня система уможливлює ефективне змістове наповнення навчальних дисциплін, а відтак результативні фундаментальні знання, професійно-спрямовані уміння, поглиблені навички, фахові норми і цінності, які мають найвищий ступінь узагальнення суспільних явищ та процесів.

Доведено, що в концепції дослідження практичної психології поєднані професійне методологування, філософські та загальнонаукові принципи й науково-методологічні підходи, які направлені на розкриття майбутньої професійної діяльності. Окреслені концептуальні засади професійної підготовки дозволяють видозмінити освітній процес у вищій школі відповідно до індивідуальних потреб майбутніх практичних психологів.

Запропоновано здійснення методологічного аналізу освітнього феномена практичної психології у закладах вищої освіти на чотирьох основних рівнях: філософсько-теоретичному (еволюційно-теоретичне становлення фахівця та його дієве функціонування), методологічному (формування системи світоглядних та смислових індивідуальних установок для реалізації власних освітніх умінь і навичок), конкретно-науковому (набуття фундаментальних знань про власну професійну діяльність) та технологічному (результативне використання методик і технік дослідження для отримання правдивого емпіричного знання).

Зроблено висновок про важливість окреслення концептуальних засад у системі професійної підготовки майбутніх практичних психологів.

Ключові слова: професійна підготовка; заклади вищої освіти; концептуальні основи професійної підготовки; студенти; майбутні практичні психологи.

(C) V. M. Synyshyna 
Introduction. Nowadays, there is a growing need in the civil society for specialist-psychologists who approach their professional activity creatively, competently and in accordance with the values of their own profession. Adaptation of the future psychologist to different social and life situations requires rapid development of new innovative technologies, continuous self-education, professional development and effective realization of the acquired professional skills and abilities in their activity.

The system of higher education of Ukraine as a whole provides the competent formation of psychologists of high level of educational training and is directed at individualization and humanization of education. Creating appropriate psycho-didactic conditions in higher education contributes to the formation of professionally significant educational qualities of future specialists, develops their creative potential, active social position and creativity.

Such educational process takes into account both the individual needs and interests of students in the selection of effective forms, means and methods of teaching by teachers, and directs it to the holistic creation of the professional picture of the world, the affirmation of professional mentality to adopt the culture and values of future clients [4]. It is important that the educational system, which is built on the conceptual foundations of professional training, provides professional-oriented training of future specialists, generates their scientific and professionally directed knowledge, skills, abilities, norms and values, and determines the effective content of educational disciplines [6].

The aim - to outline the conceptual foundations of the professional training of future practical psychologists.

Theoretical framework. The professional training of future practical psychologists in the institutions of higher education is directed at the effective acquisition of skills to obtain a highly specialized education throughout life and always serves as a valuable personal and social process for the specialist. Accordingly, the purposefulness of the content of the disciplines for professional-personal growth of students contributes to improving the quality of their educational level, influences the development of the surrounding social environment and higher education in general.

At the same time, effective mastery of the specified content of the disciplines implies the establishment of close interdisciplinary relationships directed at the formation of holistic competence knowledge in future practical psychologists, the ability to make effective practical decisions in unusual psychological situations. In this process, the personal professional position of the teacher is directed at establishing emotionalpositive relationships in the student's group, motivation for future activity and the acquisition of social competencies, which effectively confirm the formation of personality [5]. Creating optimal educational conditions is interdependent with the most active involvement of students in the holistic educational process based on the subject of educational activity.

The need to obtain universal knowledge by practical psychologists determines the outlining of the conceptual bases of their professional training for successful orientation of graduates in the chosen profession. The acquisition of fundamental knowledge is a consequence of the rapid changes taking place in the socio-cultural sphere of society. Increasing the amount of scientific information, intensification of social, professional-personal contacts between individuals allows overloading the curricula with extra knowledge, while outlining the conceptual foundations of professional training gives teacher the right to modify the educational process in accordance with the individual needs of future psychologists [6].

The analysis of theoretical-methodological ideas of scientists (A. Balakhonov, O. Baklitskaya, I. Bardus, G. Vatkovskaya, N. Garkavenko, S. Goncharenko, I. Druzhinina, S. Isaevich, V. Korneschuk, O. Lozova, O. Matvienko, L. Rebukha, R. Sirko, S. Shandruk, O. Yazvinskaya, etc.) allows stating that there is a need to introduce changes in the content filling of modern education. Outlining the conceptual foundations of professional training of future practical psychologists in institutions of higher education is directed at humanizing the educational process, forming a systemic style of thinking of students, getting rid of overloads of educational information, obtaining opportunities for creative self-development and continuous personal professional training.

We consider under the concept the system of judgments of a phenomenon that is used to understand and explain it; designation of a leading idea, concept. The concept reflects the ability to combine existing knowledge with research in the future.

The development of the concept of professional training of future practical psychologists is considered as a theoretical basis for improving the effectiveness of specialist training in institutions of higher education. The concept of the study of the phenomenon of prac- 


\section{Materials of International Scientific and Practical Conference \\ "PROFESSIONAL AND COMMUNICATION CULTURE OF THE FUTURE DOCTOR: LINGUISTIC, PEDAGOGICAL AND PHILOSOPHICAL ASPECTS”}

tical psychology combines professional methodologic, philosophical and general-scientific principles and scientific-methodological approaches that are holistically directed at revealing its essence as a professional activity. The concept of professional training of practical psychologists is based on the idea of activating the reflexive-personal and professional self-determination of the future specialist in the framework of the introduction of universally-original and activity-effective forms and methods of teaching. It relies on the understanding of professional training as an effectively-designed educational process, which forms basic knowledge, professionally significant skills and advanced skills with the highest degree of generalization of psychological-pedagogical social phenomena in the future of practical psychologists.

The conceptual provisions of scientific science determine the implementation of methodological analysis in accordance with their systematic and activity (E. Yudin), the study of the methodology of pedagogical research (V. Kraevsky), increasing the scientific-innovative capacity of universities and strengthening the teaching-research activities of employees of institutions of education (V. Lugovyy, O. Slyusarenko, J. Talanova [2]), which made it possible to distinguish general scientific methodological approaches to the study of practical psychology as a professional activity.

Most scientists analyze methodological approaches to the analysis of practical psychology in accordance with the philosophical, general scientific and specificscientific levels. However, L. Guslyakova and E. Kholostov believe that in order to effectively consider the professional activity of socio-humanitarian direction, another level should be singled out - an applied one, which is called the level of methods and techniques by another scientist V. Krayevsky [4]. V. Pisarenko distinguishes three types of methodology: partial, which is the set of methods of each particular discipline; general as joining of methods that are more general; philosophical, which serves as a system of dialectical methods, that are effective throughout all scientific knowledge [3].

However, we offered to carry out a methodological analysis of the educational phenomenon of practical psychology at four important levels: philosophicaltheoretical, methodological, concrete-scientific and technological.

Practical psychology as an activity is considered on the basis of the analysis of philosophical principles before the evaluation of this phenomenon within the first philosophical-theoretical level. It is the philosophical-theoretical level that determines the prospect of forming the professional competence of future specialists during the educational process and the content-theoretical filling of education of students in institution of higher education. The analysis of leading pedagogical theories regarding professional knowledge acquisition and professional self-development of the individual allows to distinguish leading ideas, concepts, key definitions of the research, which are directed at solving the problems of preparation of future practical psychologists in institution of higher education; to make a scientific description of facts and phenomena and to effectively analyze, summarize and synthesize them.

According to this level, the professional training of future practical psychologists actualizes the process of evolutionary formation of a specialist and its effective functioning.

The second, methodological level, acquires the features of the general-scientific methodology of scientific intelligence of professiogenesis of the future practical psychologists and consists of generalscientific approaches, characteristics of scientific research, their stages and main constituent elements: hypotheses, object and subject of research, purposes, tasks, etc. In turn, I. Zaychenko notes that the basic scientific methodology is based on theoretical concepts that are applied in all scientific disciplines or in most of them [1].

We consider the methodological level of constructing the educational process in modern pedagogical science as the initial personal foundation, as a system of outlook and meaningful individual settings, directly involved in the implementation of their own educational skills and abilities. The future specialist will have reflective attitudes that are directed at the analysis of the accumulated practical experience at this level. In this regard, the methodological level, combining theoretical, methodological and technological practice, serves as the conceptual foundation of the training system of future practical psychologists.

The third level is a concrete scientific methodology of practical psychology, which outlines a comprehensive set of theoretical knowledge of the methods, principles, techniques and effective procedures involved in the study, which are used in the training of practical psychologists. Scientific methodology of practical psychology as a system of fundamental theoretical 
knowledge about the specified professional activity is directed at primary professionalization of students. The concrete-scientific level includes both specific and higher levels of methodology, ranging from scientific knowledge of the problem to the solution of issues related to the formation or modeling of pedagogical research.

The fourth, technological, level of methodology of professiogenesis involves professional training, teaching the basic principles of the profession, special growth of each student during the educational process. This level is characterized by the effective use of research methods and techniques in higher education that provide true empirical knowledge. Initial processing of research materials (immersion in a problem) encourages every future practical psychologist to release a personal array of already existing scientific knowledge in the process of solving practically oriented problems. At this level, the acquired professional knowledge has a clear normative and activity character, which is the basis of systematic professional methodology.

The proposed levels of methodological analysis of practical psychology place certain requirements on the organization of the educational process. These

\section{List of literature}

1. Зайченко І. В. Педагогіка : підручник / І. В. Зайченко. - К. : Ліра-К, 2016. - 608 с.

2. Луговий В. Академічно-університетський дуалізм світового дослідницького простору / В. Луговий, О. Слюсаренко, Ж. Таланова // Наука та наукознавство. - 2017. - № 4 (98). - С. 84-85.

3. Писаренко В. И. Методологические проблемы современной педагогики / В. И. Писаренко // Известия Южного федерального университета. - 2013. - № 10. С. 104-109.

4. Ребуха Л. 3. Професійна підготовка майбутніх практичних психологів у закладах вищої освіти: методоло-

\section{References}

1. Zaychenko, I.V. (2016). Pedahohika: pidruchnyk [Pedagogy: textbook]. Kyiv:Lira [in Ukrainian].

2. Luhovyi, V., Sliusarenko, O., \& Talanova, J. (2017). Akademichno-universytetskyi dualism svitovoho doslidnytskoho prostoru [Academic-university dualism of the world research space]. Nauka ta naukovyzna - Science and Novelty, 4 (98), 84-85 [in Ukrainian].

3. Pisarenko, V.I. (2013). Metodologicheskie problemy sovremennoy pedagogki [Methodological problems of requirements are related to the design and modeling of the content of academic disciplines, the transformation of educational activity into a professional one through the passage of intermediate stages (educational activity - quasi-professional activity - educationalprofessional activity - professional activity). Our levels of methodological analysis of practical psychology as a future professional activity form a complex system within which there is a clear subordination.

Conclusions and Prospects for Research. The system of professional training of future practical psychologists is structured in accordance with its conceptual foundations in many levels: from the highest to the lowest (philosophical-theoretical, methodological, concrete-scientific, technological) levels. The interrelation between levels reflects the processes of professional methodologizing and collectively influences the creation of methodology of the profession genesis of future practitioners of practical psychology. Therefore, the realization of the phenomenon of professional training in the institutions of higher education requires further consideration of general scientific approaches and methodological principles for the profession genesis of future practical psychologists.

гічний аспект / Л. 3. Ребуха // Інноваційна педагогіка. 2019. - Вип. 17, т. 1. - С. 137-140.

5. Шандрук С. К. Психологічні засади розвитку професійних творчих здібностей майбутніх практичних психологів : дис. ... д-ра психол. наук : 19.00.07 / С. К. Шандрук. - Тернопіль, 2016. - 458 с.

6. Strategic significance of English in self-education of the students of socio-humanitarian specialities for fundamentalization of university education / I. Melnychuk, L. Rebukha, T. Zavgorodnia, I. Bloshchynskyi // Modern Journal of Language Teaching Methods. - 2018. No. 8 (11). - P. 712-720.

modern pedagogy]. Izvestiya yunogo federalnogo universiteta - News of the Southern Federal University, 10, 104-109 [in Russian].

4. Rebukha, L.Z. (2019). Profesiina pidhotovka maibutnikh psykholohiv u zakladakh vyshchoi osvity: metodolohichnyi aspect [Professional training of future practical psychologists in institutions of higher education: methodological aspect]. Innovatsiina pedahohika - Innovative Pedagogy, 17, 1, 137-140 [in Ukrainian]. 
5. Shandruk, S.K. (2016). Psykholohichni zasady rozvytku profesiinykh tvorchykh zdibnostei maibutnikh praktychnykh psykhologiv [Psychological principles of development of professional creative abilities of future practical psychologists]. Doctor's thesis. Ternopil [in Ukrainian].
6. Melnychuk, I., Rebukha, L., Zavgorodnia, T., \& Bloshchynskyi, I. (2018). Strategic significance of English in self-education of the students of socio-humanitarian specialities for fundamentalization of university education. Modern Journal of Language Teaching Methods, 8 (11), 712-720.

E-mail address for correspondence: vsinishina@ukr.net 